\title{
Sorption and Fractionation of Dissolved Organic Matter and Associated Phosphorus in Agricultural Soil
}

\author{
B. Gjettermann,* M. Styczen, S. Hansen, O. K. Borggaard, and H. C. B. Hansen
}

\begin{abstract}
Mobility of dissolved organic matter (DOM) strongly affects the export of nitrogen (N) and phosphorus (P) from soils to surface waters. To study the sorption and mobility of dissolved organic $\mathbf{C}$ and $\mathbf{P}$ (DOC, DOP) in soil, the pH-dependent sorption of DOM to samples from Ap, EB, and Bt horizons from a Danish agricultural Humic Hapludult was investigated and a kinetic model applicable in fieldscale models tested. Sorption experiments of 1 to $72 \mathrm{~h}$ duration were conducted at two $\mathrm{pH}$ levels (pH 5.0 and 7.0) and six initial DOC concentrations (0-4.7 $\left.\mathbf{m m o l} \mathrm{L}^{-1}\right)$. Most sorption/desorption occurred during the first few hours. Dissolved organic carbon and DOP sorption decreased strongly with increased $\mathrm{pH}$ and desorption dominated at $\mathrm{pH}$ 7, especially for DOC. Due to fractionation during DOM sorption/ desorption at DOC concentrations up to $2 \mathrm{mmol} \mathrm{L}^{-1}$, the solution fraction of DOM was enriched in $P$ indicating preferred leaching of DOP. The kinetics of sorption was expressed as a function of how far the solution DOC or DOP concentrations deviate from "equilibrium." The model was able to simulate the kinetics of DOC and DOP sorption/ desorption at all concentrations investigated and at both $\mathrm{pH}$ levels making it useful for incorporation in field-scale models for quantifying DOC and DOP dynamics.
\end{abstract}

$S^{c}$ ORPTION of dissolved organic matter (DOM) influences element mobility in soils (Guggenberger and Kaiser, 2003), and subsequently affects leaching of phosphorus and other nutrients to drains and groundwater (Grant et al., 1996). Additionally, DOM has been reported to interact with organic pollutants such as pesticides and aromatic anilines (Flores-Céspedes et al., 2006) and heavy metals (Gerritse, 1996; Ashworth and Alloway, 2004), affecting the fate of these pollutants in soil and aquatic systems. Dissolved organic matter is usually quantified in term of its carbon content, which is referred to as dissolved organic carbon (DOC); associated $\mathrm{P}$ is referred to as dissolved organic phosphorus (DOP). When leaching to deep soil layers DOM may increase the potential for denitrification by stimulating microbial activity (Vinther et al., 2005) although the bioavailability of DOM seems to be a matter of dispute (Marschner and Kalbitz, 2003; Hagedorn et al., 2004).

Despite this uncertainty, knowledge about factors affecting DOM sorption and mobility is important as a

B. Gjettermann and M. Styczen, DHI-Water and Environment, Dep. of Hydrology, Soil and Waste, Agern Allé 11, DK-2970 Hørsholm, Denmark. B. Gjettermann, S. Hansen, The Univ. of Copenhagen, Faculty of Life Sciences, Højbakkegård Allé 9, DK-2630 Taastrup, Denmark. O.K. Borggaard and H.C.B. Hansen, Dep. of Natural Sciences, The Univ. of Copenhagen, Thorvaldsensvej 40, DK-1871 Frederiksberg C, Denmark. Received 24 Feb. 2006. *Corresponding author (bgj@life.ku.dk).

Published in J. Environ. Qual. 36:753-763 (2007).

Technical Reports: Vadose Zone Processes and Chemical Transport doi:10.2134/jeq2006.0081

(c) ASA, CSSA, SSSA

677 S. Segoe Rd., Madison, WI 53711 USA basis for development of field- and catchment-scale models to predict the environmental impact of future changes of land use and climate. A couple of models include physical/chemical stabilization of DOM in soil like the DyDOC model (Michalzik et al., 2003) and the model described by Neff and Asner (2001). The DAISY field-scale model (Abrahamsen and Hansen, 2000) includes a description of biological turnover of organic matter including a DOM pool. However, procedures for describing the physical and chemical stabilization of DOM remain to be developed.

Sorption of DOM to soils depends on several factors such as concentration, $\mathrm{pH}$, time, and soil mineral composition (Moore et al., 1992; Ussiri and Johnson, 2004; Lilienfein et al., 2004). Iron and aluminum oxides are important sorbents of DOM with sorption usually described as surface complexation of DOM carboxyl groups (Kaiser et al., 1997; Shen, 1999), while the role played by $\mathrm{P}$ ester groups for DOP sorption is not clear (Qualls and Haines, 1991). However, specific monoester-phosphate compounds as inositol hexaphosphate are sorbed in preference of inorganic phosphate on goethite kaolinite and illite through the phosphate groups of inositol hexaphosphate (Celi et al., 1999). Different observations of the $\mathrm{pH}$ effect on DOM mobilization have been reported (Vance and David, 1992; Shen, 1999). Ussiri and Johnson (2004) investigated DOM sorption to mineral forest soil and found maximum sorption of DOM at $\mathrm{pH} \mathrm{4,} \mathrm{which} \mathrm{decreased} \mathrm{both} \mathrm{at} \mathrm{higher} \mathrm{and}$ lower $\mathrm{pH}$ in accordance with maximum sorption taking place at the average acidity constant of DOM, which is around pH 3 to 5 (Buffle, 1990; Cambier and Sposito, 1991). The sorption of DOM is time dependent, with a declining rate as the concentration gradient between the solution and the sorbing soil aggregate becomes smaller (Renaud et al., 2004).

Several studies show that DOM fractionation occurs in forest soil due to sorption (e.g., Kaiser et al., 1996; Ussiri and Johnson, 2004). Different sorption affinity of DOC and DOP has been attributed to different $P$ contents within DOM fractions having different affinities (Kaiser, 2001; Qualls and Haines, 1991). Wang et al. (1997) found that the more aromatic moieties of a fulvic acid on goethite were preferentially adsorbed. Hydrophobic DOM fractions are preferentially sorbed compared with hydrophilic DOM fractions (Kaiser et al., 1996) as hydrophobic DOM is relatively more rich in aromatic $\mathrm{C}$ and acidic groups than hydrophilic DOM (Kaiser, 2003). This preference results in a fractionation of the DOM according to molecular weight and as the

Abbreviations: DIP, dissolved inorganic phosphorus; DOC, dissolved organic carbon; DOM, dissolved organic matter; DON, dissolved organic nitrogen; DOP, dissolved organic phosphorus. 
elemental composition of DOM varies with the molecular weight, elemental fractionation of $\mathrm{N}, \mathrm{P}$, and $\mathrm{C}$ may be obtained as a consequence. For example, Kaiser (2001) and Qualls and Haines (1991) observed for forest soils that the hydrophilic fraction contained the vast majority of DOP and sorbed far less than the hydrophobic fraction, resulting in less overall retention of DOP than DOC. Sorption of DOM has received less attention in agricultural soils and to our knowledge no studies have reported a comparison of DOC and DOP sorption.

The aims of the present study were to test if DOM sorption to agricultural soils leads to fractionation of DOC and DOP, and to quantify to which extent sorption and fractionation depends on $\mathrm{pH}, \mathrm{DOM}$ concentration, time, and soil composition. Focus has been on the use of conventional measures of DOC and DOP, and quantification using simple submodels for sorption and desorption dynamics for future incorporation into the field-scale model DAISY (Gjettermann et al., 2006). The study was based on batch sorption experiments using DOM extracted from an agricultural Ap horizon by a chelating resin.

\section{MATERIALS AND METHODS \\ Site and Soil Description}

The soil used for the study is located at the Burrehøjvej field at Research Center Foulum in the central part of Jutland, Denmark $\left(9^{\circ} 34^{\prime} \mathrm{E}, 56^{\circ} 29^{\prime} \mathrm{N}\right)$. The soil sampled in 2002 is a Humic Hapludult (Soil Survey Staff, 1999) developed on noncalcareous, clayey till (ground moraine) deposited during the Weichselian Glaciation; mean annual soil temperature is $8.1^{\circ} \mathrm{C}$ and mean annual precipitation is $680 \mathrm{~mm}$. In the previous $9 \mathrm{yr}$ (1994-2002) the soil has been covered by grass-clover and grazed by dairy cattle approximately $150 \mathrm{~d} \mathrm{yr}^{-1}$. Due to the continuous input of organic matter by the grazing cattle and $\mathrm{N}$ fixation by the grass-clover the field had been used to study mobilization and transport of DOM and how this affects denitrification. Soil was sampled according to the genetic horizons, Ap $(0-30 \mathrm{~cm})$, EB $(30-70 \mathrm{~cm})$, and Bt $(70-130 \mathrm{~cm})$. For soil sample characterization, air-dried and sieved (through a 2-mm sieve) soil was used. For sorption experiments, moist soil samples with a water content of 12 to $21 \%$ were stored in a refrigerator at $5^{\circ} \mathrm{C}$ until used. The precise water content in each sample was estimated every time a sorption experiment was performed by heating $5.0 \mathrm{~g}$ of moist soil at $105^{\circ} \mathrm{C}$ until constant weight. Three replicates were made each time.

\section{Soil Analyses}

Soil texture was determined by sieving and hydrometer measurements after dispersion in $0.002 M$ sodium pyrophosphate (Gee and Bauder, 1986). The $\mathrm{pH}$ was measured in $0.01 \mathrm{M} \mathrm{CaCl}_{2}$ suspension with a 1:2.5 soil/solution ratio. The electrical conductivity was measured in the extract from 1:5 soil/water suspension (Slavich and Petterson, 1993). Exchangeable $\mathrm{Ca}, \mathrm{Mg}, \mathrm{K}$, and $\mathrm{Na}$ cations at $\mathrm{pH} 7$ of the soil samples were determined by the ammonium acetate method (Chapman, 1965). Oxalate-extractable $\mathrm{Al}$ and Fe were determined after extraction of ground soil $(<250 \mu \mathrm{m})$ for $2 \mathrm{~h}$ with $0.2 \mathrm{M}$ ammonium oxalate at $\mathrm{pH} 3$ in the dark (Schwertmann, 1964). Citrate-bicarbonate-dithionite (CBD)-extractable Al and $\mathrm{Fe}$ were determined after two extractions of soil (ground $<250 \mu \mathrm{m}$ ) for $15 \mathrm{~min}$ at $70^{\circ} \mathrm{C}$ (Mehra and Jackson, 1960).
Total carbon content was determined by dry combustion at $1250^{\circ} \mathrm{C}$ in oxygen (ELTRA, 1995). Total $\mathrm{N}$ content of soil samples was determined by the Kjeldahl method using $3.0 \mathrm{~g}$ of soil. Inorganic $\mathrm{P}$ and total $\mathrm{P}$ contents of soil samples were determined by extracting $0.5 \mathrm{~g}$ ground soil (ground to particle sizes $<250 \mu \mathrm{m}$ ) with $5.0 \mathrm{~mL} 6.0 \mathrm{M}$ sulfuric acid $\left(\mathrm{H}_{2} \mathrm{SO}_{4}\right)$ for $10 \mathrm{~min}$ with and without pre-ignition at $550^{\circ} \mathrm{C}$ for $1 \mathrm{~h}$ before extraction, respectively (Szilas et al., 1998). Phosphate was measured by flow injection analysis (Tecator FIAstar 5012 Analyzer, Tecator/Foss, Höganäs, Sweden) as molybdate reactive P (MRP) by the molybdenum blue/stannous chloride method at $690 \mathrm{~nm}$ (Janse et al., 1983). The chemical data and particle size distribution for the Ap, EB, and Bt horizon of Burrehøjvej field soil are listed in Table 1. All soil analyses were done in triplicates.

\section{Dissolved Organic Matter Stock Solution}

Stock solution of DOM for the sorption experiments was extracted from the Ap horizon using a chelating, sodium saturated resin, Chelex 100 Resin, 100-200 mesh (BioRad, Herlev, Denmark). Before use the resin was rinsed repeatedly in tripledeionized water (TI water). Extraction of DOM was performed as follows: $10.0 \mathrm{~g}$ of air-dried and sieved soil from the Ap horizon and $50 \mathrm{~g}$ of wet resin were added to $200 \mathrm{~mL}$ of TI water in a $500-\mathrm{mL}$ polyethylene bottle. Nine replicates were made in addition to two blanks with no soil. The bottles were kept at room temperature and gently turned upside down manually twice per day, as shaking has been found to result in release of organic substances from the resin contaminating blanks as well as DOM extracts. After $5 \mathrm{~d}$ of extraction, the extract was separated from soil and resin by centrifugation $(6700 \mathrm{~g})$ followed by filtration through $0.45-\mu \mathrm{m}$ Millipore filter of regenerated cellulose. During these steps $<1 \%$ of DOC was removed from the DOM extract by centrifugation and additionally $\sim 4 \%$ of DOC was lost due to filtration. The DOM extracts were stored in Blue Cap bottles at $5^{\circ} \mathrm{C}$.

The contents of metals ( $\mathrm{Fe}, \mathrm{Al}, \mathrm{Ca}, \mathrm{Mg}$, and $\mathrm{K}$ ) as well as of DOC and DOP were determined in the DOM extracts. The concentrations of $\mathrm{Fe}, \mathrm{Al}$, and $\mathrm{Ca}$ (in $5 \% \mathrm{LaCl}_{3}$ ) were determined by flame atomic absorption spectroscopy (FAAS), $\mathrm{Mg}$

Table 1. Soil characteristics of Burrehøjvej field soil. $\dagger$

\begin{tabular}{|c|c|c|c|c|}
\hline \multicolumn{2}{|l|}{ Parameter } & \multirow{2}{*}{$\begin{array}{c}\text { Ap horizon } \\
5.68 \pm 0.02\end{array}$} & \multirow{2}{*}{$\begin{array}{c}\text { EB horizon } \\
5.75 \pm 0.005 \\
\mathrm{~cm}\end{array}$} & \multirow{2}{*}{$\begin{array}{l}\text { Bt horizon } \\
4.27 \pm 0.02 \\
\end{array}$} \\
\hline pH $\left(\mathrm{CaCl}_{2}\right)$ & & & & \\
\hline Depth & & 0-30 & $\begin{array}{r}30-70 \\
-\mathrm{g} \mathrm{kg}^{-1} \\
\end{array}$ & 70-130 \\
\hline Particle sizes & $\begin{array}{l}<2 \mu \mathrm{m} \\
2-20 \mu \mathrm{m} \\
20-200 \mu \mathrm{m}\end{array}$ & $\begin{array}{r}68 \pm 0 \\
127 \pm 1 \\
805 \pm 1\end{array}$ & $\begin{array}{c}126 \pm 3 \\
114 \pm 0.5 \\
760 \pm 1 \\
-m^{2}=k^{-1}\end{array}$ & $\begin{array}{r}148 \pm 0 \\
97 \pm \mathbf{1} \\
755 \pm \mathbf{3}\end{array}$ \\
\hline Nutrients & $\begin{array}{l}\text { Total C } \\
\text { Total N } \\
\text { Total P }\end{array}$ & $\begin{aligned} \mathbf{2 5 0 6} & \pm \mathbf{2 1} \\
\mathbf{1 4 3} & \pm \mathbf{2} \\
\mathbf{2 6} & \pm \mathbf{0 . 4}\end{aligned}$ & $\begin{array}{r}118 \pm \mathbf{4 5} \\
7 \pm \mathbf{0 . 3} \\
9 \pm \mathbf{0 . 2}\end{array}$ & $\begin{aligned} 63 & \pm 6 \\
4 & \pm 0.2 \\
7 & \pm 0.1\end{aligned}$ \\
\hline $\begin{array}{l}\text { Aluminum and } \\
\text { iron fractions }\end{array}$ & $\begin{array}{l}\mathbf{A l}_{\text {cbd }} \\
\mathbf{A l}_{\text {ox }} \\
\mathrm{Fe}_{\text {exd }} \\
\mathrm{Fe}_{\text {ox }}\end{array}$ & $\begin{aligned} 133 & \pm 2 \\
111 & \pm 1 \\
80 & \pm 2 \\
62 & \pm 1\end{aligned}$ & $\begin{aligned} 115 & \pm 11 \\
81 & \pm 14 \\
77 & \pm 9 \\
22 & \pm 3\end{aligned}$ & $\begin{array}{l}71 \pm 13 \\
62 \pm 15 \\
83 \pm 2 \\
32 \pm 6\end{array}$ \\
\hline $\begin{array}{l}\text { Exchangeable } \\
\text { cations }\end{array}$ & $\begin{array}{l}\mathrm{Ca} \\
\mathrm{Mg} \\
\mathrm{K} \\
\mathrm{Na} \\
\mathrm{CEC}_{7}\end{array}$ & $\begin{aligned} \mathbf{8 1} & \pm \mathbf{3} \\
\mathbf{5} & \pm \mathbf{0 . 2} \\
\mathbf{3} & \pm \mathbf{0 . 0 3} \\
\mathbf{1} & \pm \mathbf{0 . 0 2} \\
\mathbf{1 0 4} & \pm \mathbf{0 . 3}\end{aligned}$ & $\begin{aligned} 21 & \pm \mathbf{0 . 4} \\
1 & \pm \mathbf{0 . 0 4} \\
\mathbf{1} & \pm \mathbf{0 . 0 7} \\
\mathbf{1} & \pm \mathbf{0 . 1} \\
\mathbf{4 7} & \pm \mathbf{0 . 4}\end{aligned}$ & $\begin{aligned} 22 & \pm \mathbf{1} \\
\mathbf{5} & \pm \mathbf{0 . 1} \\
\mathbf{1} & \pm \mathbf{0 . 0 2} \\
\mathbf{1} & \pm \mathbf{0 . 0 2} \\
\mathbf{5 8} & \pm \mathbf{0 . 7}\end{aligned}$ \\
\hline & $\mathbf{B S}_{7}$ & $86 \pm 3$ & $51 \pm 1$ & $50 \pm 1$ \\
\hline
\end{tabular}

$\dagger$ ox, oxalate extracted; cbd, citrate-bicarbonate-dithionite extracted; BS, base saturation; CEC, cation exchange capacity. 
was determined by graphite furnace atomic absorption spectroscopy (GFAAS), and $\mathrm{K}$ was determined by flame emission spectroscopy (FES). The determination of $\mathrm{C}$ and $\mathrm{P}$ in the DOM extract is described below. The concentrations of metals, DOC and DOP in the DOM stock solution, and blanks are shown in Table 2. The contents of carboxylic and phenolic groups were determined by acid/base titration. While flushing with moist Ar, $2.00 \mathrm{~mL}$ of DOM and $8 \mathrm{~mL}$ of water were titrated (downscale) with $0.01 \mathrm{M} \mathrm{HCl}$ to $\mathrm{pH} \mathrm{3}$, and then the solution was titrated (upscale) with $0.01 M \mathrm{NaOH}$ to $\mathrm{pH}$ 11. Blank titrations were performed similarly but using $5.00 \mathrm{~mL} 0.01 \mathrm{M}$ $\mathrm{NaOH}+5 \mathrm{~mL} 0.2 \mathrm{M} \mathrm{NaCl}$ instead of diluted DOM solution. The titration curves showed no clear inflection points and the contents of carboxylic and phenolic groups were taken as acid or base equivalents needed to bring $\mathrm{pH}$ from 3 to $7(\mathrm{COOH})$ and from 7 to $11(\mathrm{OH})$, or vice versa, both corrected for blank.

\section{Dissolved Organic Matter Sorption Experiments}

To investigate DOM sorption, six series of sorption experiments were conducted at two $\mathrm{pH}$ levels for each of the three horizons. One series comprised two replicates of six glass bottles (Blue Cap, Schott AG, Mainz, Germany) containing moist soil/solution in a ratio of $1: 10$ and $10 \mathrm{mM} \mathrm{NaCl}$. The $\mathrm{NaCl}$ was selected as the electrolyte instead of $\mathrm{CaCl}_{2}$ to avoid phosphate in DOP from forming complexes with $\mathrm{Ca}^{2+}$ and to hinder precipitation. The two replicates of six bottles were added $0,0.4$, $0.8,1.7,3.4$, and $4.7 \mathrm{~m} M$ DOC, respectively. Thus, one series comprised 12 bottles with $\mathrm{pH}$ adjusted to 5.0 or 7.0 . Before adding DOM, the $\mathrm{pH}$ of each suspension (consisting of $20 \mathrm{~g}$ of moist soil and $150 \mathrm{~mL}$ of TI water plus $2.0-1.8 \mathrm{~mL}$ of $1 \mathrm{M}$ $\mathrm{NaCl}$ ) was adjusted to $\mathrm{pH} 5.0$ or 7.0 using $0.01 \mathrm{M} \mathrm{HCl} / \mathrm{NaOH}$. The $\mathrm{pH}$ was measured and adjusted if needed twice during the following couple of hours and again the following day, right before addition of the remaining TI water to reach a total of $200 \mathrm{~mL}$ solution, including the final addition of DOM stock solution. After the addition of 0 to $15 \mathrm{~mL}$ of DOM stock solution, the bottles were shaken on a shaking table (30 strokes $\left.\mathrm{min}^{-1}\right)$. The concentration of DOC and DOP in solution was followed by sampling $10 \mathrm{~mL}$ of suspension after 1,120,1440, and $4320 \mathrm{~min}$ of reaction. Immediately after removal, the suspensions were centrifuged $(6700 \mathrm{~g})$ and filtered through $0.45-\mu \mathrm{m}$ Millipore filters (regenerated cellulose, Frisenette, Knebel, Denmark). It was tested that the Millipore filters did not sorb DOM. The $\mathrm{pH}$ was measured and adjusted before each sampling.

\section{Chemical Analyses}

The contents of DOC and DOP in the supernatants and DOM extract were determined as follows: DOC was deter-

Table 2. Characterizations of the dissolved organic matter (DOM) extracted from the Ap horizon and blanks (with no soil).

\begin{tabular}{lcc}
\hline Parameter & DOM extract & Blank \\
\cline { 2 - 3 } DOC $\dagger$ & \multicolumn{1}{c}{ mmol L $^{-1}$} & \\
DIP & $\mathbf{6 3} \pm \mathbf{1}$ & $\mathbf{1 . 3} \pm \mathbf{0 . 1}$ \\
DOP & $\mathbf{0 . 4 0} \pm \mathbf{0 . 0 1}$ & $-\ddagger$ \\
Carboxylic groups & $5.5 \pm \mathbf{0 . 3}$ & - \\
Phenolic groups & $3.9 \pm 0.2$ & - \\
Fe & $\mathbf{0 . 4 7} \pm \mathbf{0 . 0 3}$ & - \\
Al & $3.1 \pm \mathbf{0 . 2}$ & $\mathbf{0 \S}$ \\
Ca & $\mathbf{0 . 0 5} \pm \mathbf{0 . 0 2}$ & $\mathbf{0}$ \\
K & $\mathbf{0 . 1 0} \pm \mathbf{0 . 0 1}$ & $\mathbf{0}$ \\
Mg & $\mathbf{0 . 0 6} \pm \mathbf{0 . 0 2}$ & $\mathbf{0}$ \\
\hline
\end{tabular}

† DIP, dissolved organic phosphorus; DOC, dissolved organic matter; DOP, dissolved organic phosphorus.

$\$$ Not measured.

$\S$ Below detection limit. mined using a total organic carbon analyzer (Shimadzu TOC500, Shimadzu Corporation, Kyoto, Japan.). The DOP solute concentration was defined as the difference between measured total dissolved P (TDP) and measured dissolved inorganic phosphorus (DIP) in solution. Dissolved inorganic phosphorus was measured directly in the sample by the molybdate method. Total dissolved phosphorus was determined by a modification of a method proposed by Bedrock et al. (1995) for measuring organic $\mathrm{P}$ in humic and fulvic acids. One-mL of solution was evaporated to dryness at $70^{\circ} \mathrm{C}$ followed by ignition at $550{ }^{\circ} \mathrm{C}$ for $1 \mathrm{~h}$. The residue was added $0.25 \mathrm{~mL} 6 \mathrm{M} \mathrm{H}_{2} \mathrm{SO}_{4}$, left $1 \mathrm{~h}$, and then added $0.5 \mathrm{~mL}$ of TI water. After complete dissolution, the extracts were transferred to a 10 to $25 \mathrm{~mL}$ volumetric flask and TI water added to volume. The phosphate concentration was determined by the molybdenum blue method as described above.

\section{Data Analysis}

Sorption curves were plotted showing the adsorbed amount of sorbate as a function of solution concentrations with time for DOC and DOP. Sorbed DOC and DOP were calculated as the difference between added and measured DOC and DOP in solution. To fit the sorption curves for DOC and DOP to soil materials, which already contain DOC and DOP, the curves were fitted by a model that took into account desorption of DOC and DOP. The Initial Mass (IM) isotherm developed by Nodvin et al. (1986) has in several studies been able to describe the amount of DOC, DON (dissolved organic nitrogen), and DOP removed or released to the solution by the soil, as a linear function of the initial amount, $X_{i}$, added to the soil-water system (Moore et al., 1992; Kaiser and Zech, 2000; Kaiser, 2001). In this approach the amount of substance removed or released, $R E$ (normalized to soil mass, units in $\mathrm{mmol} \mathrm{kg}^{-1}$ ), is plotted as a function of the initial amount of sorbate $X_{i}$ (normalized to soil mass, units in $\mathrm{mmol} \mathrm{kg}^{-1}$ ). The release or removal of DOC or DOP is then given by Eq. [1]:

$$
R E=m X_{i}-b
$$

where the slope of the partition regression, $m$ (given as a fraction), is similar to the partition coefficient. The intercept of the linear regression, $b\left(\mathrm{mmol} \mathrm{kg}^{-1}\right)$, indicates the amount of sorbate released from the soil when a solution with a zero sorbate concentration is added (Nodvin et al., 1986). The parameters $m$ and $b$ were estimated for all DOC and DOP sorption isotherms.

When no DOM is removed from or released to the solution then $R E=0$. Inserting $R E=0$ into Eq. [1], the amount of DOM in solution (normalized to soil mass, units in $\mathrm{mmol} \mathrm{kg}^{-1}$ ) at this point, $X_{0}$, is given by Eq. [2]:

$$
X_{0}=\frac{b}{m}
$$

Transferring the $X_{0}$ from per soil mass units to per soil solution unit, $C_{\mathrm{np}}$, was done by taking the soil/water ratio into account, resulting in Eq. [3], where $M(\mathrm{~kg})$ is the soil mass and $V(\mathrm{~L})$ is the volume of the solution:

$$
C_{\mathrm{np}}=X_{0} \frac{M}{V}
$$

The $C_{\mathrm{np}}$ (here referred to as the nil-point concentration given in mmol $\mathrm{L}^{-1}$ ) is the DOC or DOP solution concentration where no net sorption takes place and the concentration that the soil system will approach with time, given that contact time has been long enough to ensure that steady-state conditions prevail. Under these conditions $C_{\mathrm{np}}$ ought to be independent 
of the initial concentration of added DOM and DOP. Pedotransfer functions estimating the parameters $m$ and $b$ might be useful in estimating $C_{\mathrm{np}}$ specific for a given soil with defined soil properties. Pedotransfer functions are physical-mathematical models, which in the absence of direct measurements, allow estimating of, e.g., soil hydraulic properties (Fila et al., 2006) or soil sorption properties for nutrients (Borggaard et al., 2004), or metals (Horn et al., 2006) from soil data. Pedotransfer functions represent a valuable tool for providing agroecological models with soil input estimations (Fila et al., 2006).

In another, kinetic approach to model sorption processes, the existence of an apparent "equilibrium" solution concentration $\left(C_{\text {eq }}, \mathrm{mmol} \mathrm{L}^{-1}\right)$ at which no net sorption/desorption takes place is used in several mathematical models (Abrahamsen and Hansen, 2000; DHI Water and Environment, 2001) for describing exchange of ammonia and pesticides with soil. In this approach, the exchange of DOC and DOP between the dissolved and solid phases is described by a first-order reaction; where it is assumed that the sorption or desorption only depends on the solute concentration. The change of DOC or DOP concentration, $C\left(\mathrm{mmol} \mathrm{L}^{-1}\right)$, in solution with time, $t(\mathrm{~h})$, is given by:

$$
\frac{d C}{d t}=-k\left(C-C_{\mathrm{eq}}\right)
$$

assuming that desorption and sorption rate constants were equal, $k\left(\mathrm{~h}^{-1}\right)$. Equation [4] may be integrated into Eq. [5] and [6]:

$$
\begin{gathered}
\int_{C_{0}}^{C} \frac{1}{C-C_{\mathrm{eq}}} d C=-k \int_{t_{0}=1 / 60}^{t} d t \\
C=C_{\mathrm{eq}}+\left(C_{0}-C_{\mathrm{eq}}\right) \exp \left(-k t+\frac{k}{60}\right)
\end{gathered}
$$

The amount of DOM that the soil had released during the equilibration time before DOM was added was unknown. Therefore, the integration was solved from the time $t_{0}=1 / 60 \mathrm{~h}$, which was the time when the first sample with concentration $C_{0}$ $\left(\mathrm{mmol} \mathrm{L}{ }^{-1}\right)$ was defined. From the sorption experiments the dataset $(C, t)$ from each horizon and $\mathrm{pH}$ value were fitted to Eq. [6] by adjusting the two parameters $C_{\text {eq }}$ and $k$. If Eq. [6] is linearized as a function of $\ln \left[\left(\mathrm{C}-\mathrm{C}_{\mathrm{eq}}\right) /\left(\mathrm{C}_{0}-\mathrm{C}_{\mathrm{eq}}\right)\right]$, then $k$ is a parameter obtained from linear regression. The optimization was obtained by adjusting the model parameters $C_{\text {eq }}$ and $k$ to minimize the difference between predicted and measured values using the "Solver" function in Excel (Wraith and Or, 1998).

The kinetics given by Eq. [4] must be considered as an empirical, kinetic expression linking the difference in concentration between actual and "equilibrium" concentration in the soil system. Hence, in a simplified view it lumps together considerations as diffusion and sorption kinetics into the description of the DOC and DOP sorption and desorption.

\section{RESULTS}

\section{Soil and Dissolved Organic Matter Characteristics}

The soil samples from the Ap, EB, and Bt horizons were non-calcareous and contained 7 to $15 \%$ clay. The clay content increased noticeably with increasing depth in the soil. The cation exchange capacity at pH 7 (CEC7) values for the soil were around $100 \mathrm{mmol}(+) \mathrm{kg}^{-1}$ for the top horizon and half the size for the sub horizons. Oxalate-extractable $\mathrm{Al}$ and $\mathrm{Fe}$ as well as citrate- bicarbonate-dithionite-extractable Al decreased substantially from topsoil to subsoil, while citrate-bicarbonate-dithionite-extractable Fe was almost constant. The Ap horizon contained 5.2\% soil organic matter (SOM). The total $\mathrm{C} / \mathrm{N} / \mathrm{P}$ mole ratio of the Ap horizon was 100:5.7:1.0 (Table 1). The continuous $\mathrm{N}$ fixation by the grass-clover during the last $9 \mathrm{yr}$ had made the total $\mathrm{N}$ content higher than the total $\mathrm{P}$ content in the topsoil. This was not the case in the subsoil where total $\mathrm{P}$ content was higher than total $\mathrm{N}$ due to $\mathrm{P}$ accumulation.

The chemical composition of the DOM stock solution is listed in Table 2. The DOC/DOP ratio was 158 but the DOC/TDP ratio was similar to that of the soil as inorganic $\mathrm{P}$ made up one third of total dissolved $\mathrm{P}$. Approximately $50 \%$ of the total $\mathrm{C}$ and $46 \%$ of total $\mathrm{P}$ in the soil could be extracted from the Ap horizon by use of a chelating resin using a soil/solution ratio of 1:20 (Tables 1 and 2). This indicated that a large fraction of soil humic substances could be mobilized by removing metal ions from the organic matter fraction, i.e., at least half of the humic substances were kept precipitated by metal ions (presumably di- and trivalent cations). This is comparable with the findings of Yang et al. (2001) who extracted DOM from a weathered soil using various complexing agents that mobilized polyvalent metal ions, particularly $\mathrm{Fe}$ and $\mathrm{Al}$ from the soil resulting in mobilization of soil organic matter.

The large extractable DOM fraction probably contained both newly formed and old humic substances. The content of carboxylic and phenolic groups corresponded to $7.2 \pm 0.3 \mathrm{mmol} \mathrm{COOH} \mathrm{g}{ }^{-1} \mathrm{DOC}$ and $5.1 \pm$ $0.3 \mathrm{mmol} \mathrm{OH} \mathrm{g}^{-1} \mathrm{DOC}$, respectively. If DOM was assumed to contain $50 \% \mathrm{C}$, these contents corresponded to $3.6 \mathrm{mmol} \mathrm{COOH} \mathrm{g}^{-1} \mathrm{DOM}$ and $2.6 \mathrm{mmol} \mathrm{OH} \mathrm{g}^{-1}$ DOM, which were in good agreement with carboxylic and phenolic group content of humic acids and lower than found in most fulvic acids (Buffle, 1990).

\section{Rate of Sorption}

In general, the sorption curves of DOC and DOP had slightly convex shapes and sorption increased with time of reaction (Fig. 1 and 2). Negative sorption in the low concentration range was observed for all systems tested, which were due to desorption of DOC and DOP from the soil to the solution. Also, a notable effect of $\mathrm{pH}$ on especially DOC sorption was reflected by the slopes of the curves and their intersections with the ordinate axis. The DOC and DOP sorption were fitted to IM isotherms (Eq. [1]) applying to contact times of $1 \mathrm{~min}, 2 \mathrm{~h}$, $24 \mathrm{~h}$, and $72 \mathrm{~h}$. The fitted $m$, and $b, C_{\mathrm{np}}$, and the linear correlation coefficients for the three horizons at $\mathrm{pH} 5$ and 7 are listed in Tables 3 and 4 for DOC and DOP, respectively. The values of $m$ and $b$ in Tables 3 and 4 are not directly comparable to the slope and interception of the curves in Fig. 1 and 2 as these curves are "true isotherms" and not the IM isotherms used to determine $m$ and $b$. By linear regression analysis of the IM isotherms, all three horizons could be described accurately for DOC and DOP sorption/desorption after 24 and $72 \mathrm{~h}$ 

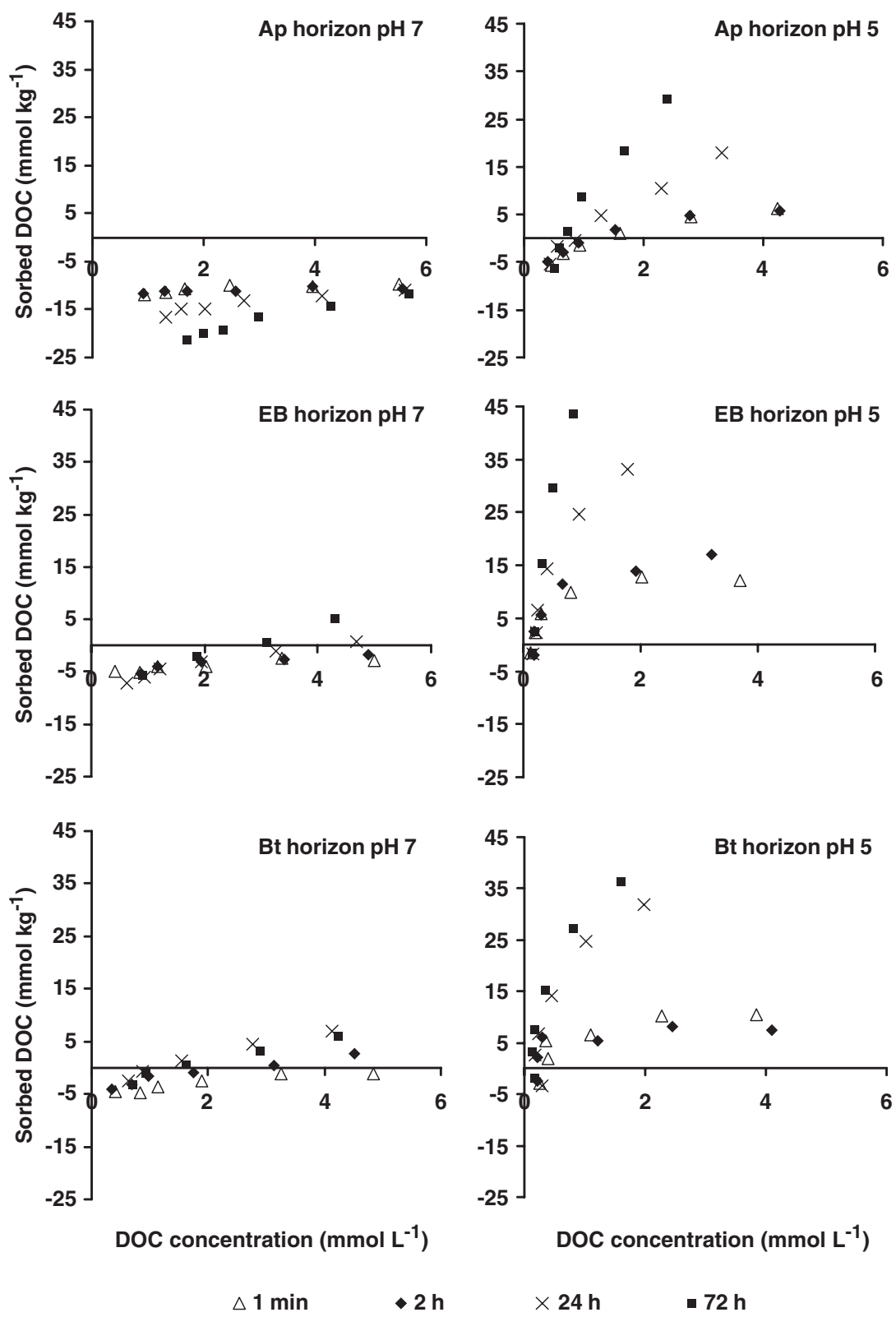

$$
\times 24 \mathrm{~h} \quad-72 \mathrm{~h}
$$

Fig. 1. Effect of pH on dissolved organic carbon (DOC) sorption showing adsorbed DOC as function of DOC in solution with time for the Ap, EB, and Bt horizons. Left: pH 7, right: pH 5. Dots indicate average of two replicates.

of reactions with correlation coefficients in the range of 0.92 to 0.99 and 0.81 to 0.99 , respectively. After 1 min and $2 \mathrm{~h}$ the correlations were less accurately described with correlation coefficients in the range of 0.59 to 0.96 and 0.70 to 0.98 for DOC and DOP, respectively (Tables 3 and 4).

The affinity for sorption of DOC was higher for the EB and Bt horizons than for the Ap horizon, reflected by the steepness of the curves (Fig. 1). For DOC the partitioning coefficients were higher for the Bt horizon than for the Ap horizon, confirming the observation of higher affinity for DOC sorption in the subsoil horizons (Table 3). At pH 5 all horizons sorbed DOM at concentration levels above $1.0 \mathrm{~m} M$ DOC, and after $3 \mathrm{~d}$ of reaction no sorption maximum was observed even at the highest DOC concentrations applied. At pH 7, sorption was markedly decreased compared with $\mathrm{pH} 5$ and the Ap horizon desorbed DOM within the tested range of DOC concentrations (Fig. 1).

The DOP sorption curves for the Ap, EB, and Bt horizons, at $\mathrm{pH} 5$ and 7 , for different times of reaction are shown in Fig. 2. Sorption of DOP to Ap and EB samples was almost the same at $\mathrm{pH} 7$ as at $\mathrm{pH}$ 5. In contrast, for the Bt sample sorption at $\mathrm{pH} 7$ was markedly lower than at $\mathrm{pH} 5$. Hence, at $\mathrm{pH} 7$ the $\mathrm{Bt}$ horizon desorbed DOP even at the highest DOP concentration applied. At pH 5 all horizons sorbed DOP at concentration levels above $0.02 \mathrm{~m} M$ DOP. The affinity for DOP was approximately the same in all horizons and after $3 \mathrm{~d}$ of reaction no sorption maxima were observed. However, the affinity was lower at $\mathrm{pH} 7$ than at $\mathrm{pH} 5$ (Table 4) within the tested range of DOP concentrations. 

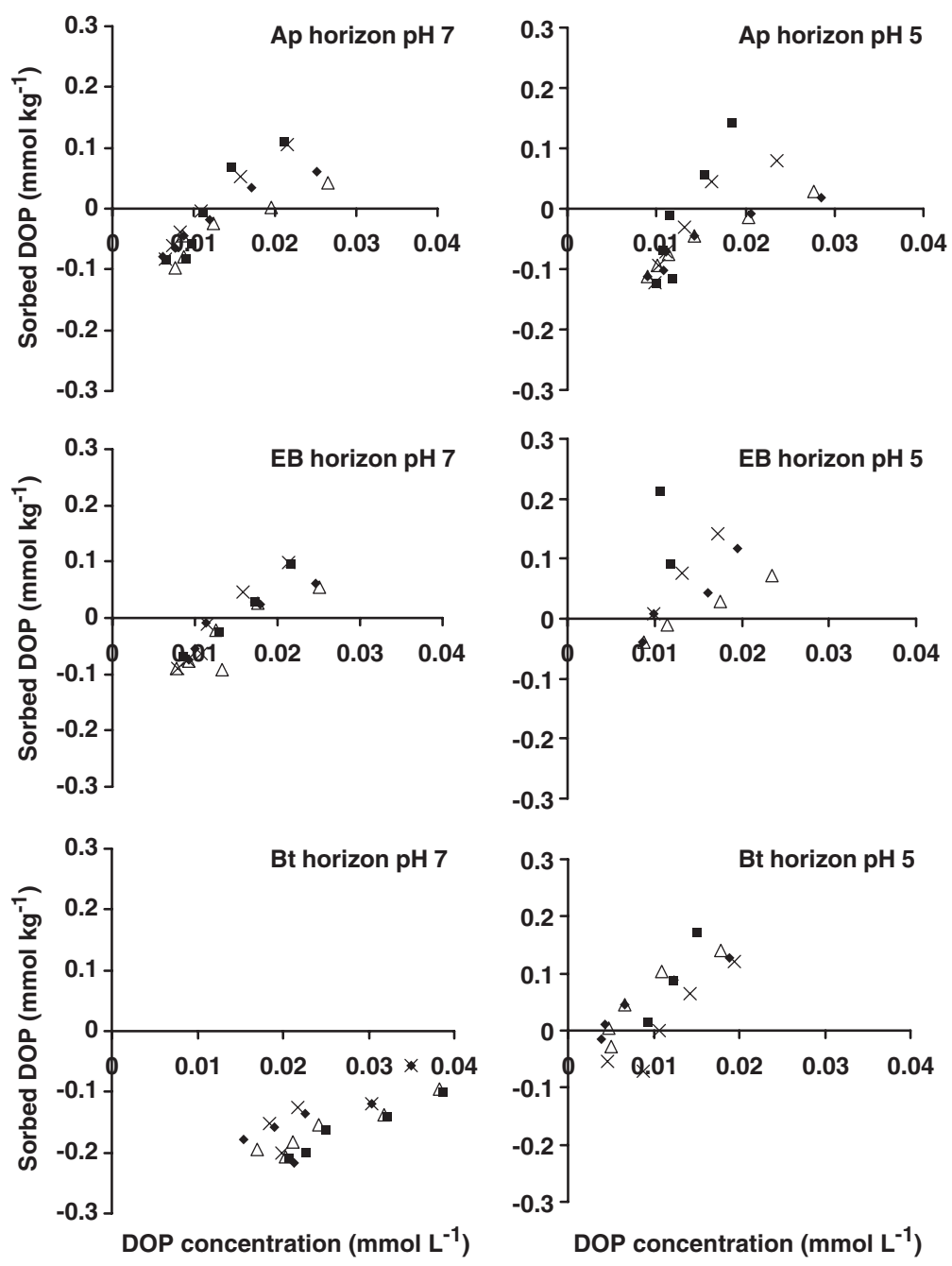

$\triangle 1 \min \quad 2 \mathrm{~h} \quad \times 24 \mathrm{~h} \quad .72 \mathrm{~h}$

Fig. 2. Effect of $\mathrm{pH}$ on dissolved organic phosphorus (DOP) sorption showing adsorbed DOP as function of DOP in solution with time for the Ap, EB, and Bt horizons. Left: pH 7, right: pH 5. Dots indicate average of two replicates.

Sorption of DOC strongly increased with time in particular at $\mathrm{pH} 5$ and at higher DOC concentrations (Fig. 1). In general, the partition coefficient, $m$, increased with time for DOC and DOP sorption confirming that DOC and DOP sorption increased with time (Tables 3 and 4 ). The estimated $C_{\mathrm{np}}$ in Tables 3 and 4 is seen to decrease or increase with time depending on whether sorption or desorption prevails. When desorption was dominating,

Table 3. Fitted partition coefficients, $m$, the parameter, $b$, the nil-point concentration, $C_{n p}$, and the correlation coefficients, $r^{2}$, for the dissolved organic carbon (DOC) initial mass (IM) isotherms for the Ap, EB, and Bt horizons at pH 5 and pH 7 (in parenthesis).

\begin{tabular}{|c|c|c|c|c|c|c|c|c|c|}
\hline $\begin{array}{l}\text { IM parameter } \\
\text { m }\end{array}$ & $\begin{array}{c}\text { Horizon } \\
\text { Ap }\end{array}$ & \multicolumn{2}{|c|}{$1 \mathrm{~min}$} & \multicolumn{2}{|c|}{$2 \mathrm{~h}$} & \multicolumn{2}{|c|}{$24 \mathrm{~h}$} & \multicolumn{2}{|c|}{$72 \mathrm{~h}$} \\
\hline$m$ & $\begin{array}{l}\text { Ap } \\
\text { EB } \\
\mathbf{B t}\end{array}$ & $\begin{array}{l}0.20 \\
0.24 \\
0.23\end{array}$ & $\begin{array}{l}(0.03) \\
(\mathbf{0 . 0 4 )} \\
(\mathbf{0 . 0 8 )}\end{array}$ & $\begin{array}{l}0.18 \\
0.33 \\
0.14\end{array}$ & $\begin{array}{r}(0.02) \\
(0.06) \\
(0.11) \\
\text { mn }\end{array}$ & $\begin{array}{l}0.38 \\
0.66 \\
0.63\end{array}$ & $\begin{array}{l}(0.09) \\
(0.14) \\
(0.20)\end{array}$ & $\begin{array}{l}0.59 \\
0.86 \\
0.69\end{array}$ & $\begin{array}{l}(0.15) \\
(0.22) \\
(0.19)\end{array}$ \\
\hline$-\boldsymbol{b}$ & $\begin{array}{l}\text { Ap } \\
\text { EB } \\
\text { Bt }\end{array}$ & $\begin{array}{r}4.06 \\
-2.02 \\
-0.28 \\
\end{array}$ & $\begin{array}{r}(11.36) \\
(4.82) \\
(4.54)\end{array}$ & $\begin{array}{r}\mathbf{3 . 3 9} \\
-\mathbf{1 . 3 8} \\
-\mathbf{1 . 4 9} \\
\end{array}$ & $\begin{array}{r}(11.44) \\
(4.98) \\
(3.46) \\
-\mathbf{m r}\end{array}$ & $\begin{array}{l}4.23 \\
0.21 \\
0.34 \\
\end{array}$ & $\begin{array}{r}(15.76) \\
(6.35) \\
(3.13)\end{array}$ & $\begin{array}{r}4.88 \\
1.18 \\
-0.33 \\
\end{array}$ & $\begin{array}{r}(\mathbf{2 0 . 5 7 )} \\
(\mathbf{6 . 7 3 )} \\
(\mathbf{3 . 6 6 )}\end{array}$ \\
\hline$C_{\mathrm{np}}$ & $\begin{array}{l}\text { Ap } \\
\text { EB } \\
\text { Bt }\end{array}$ & $\begin{array}{r}1.69 \\
-0.75 \\
-0.11\end{array}$ & $\begin{array}{r}(28.86) \\
(9.41) \\
(5.18)\end{array}$ & $\begin{array}{r}\mathbf{1 . 5 4} \\
-\mathbf{0 . 3 7} \\
-\mathbf{0 . 8 9}\end{array}$ & $\begin{array}{r}(47.10) \\
(6.78) \\
(2.64)\end{array}$ & $\begin{array}{l}0.90 \\
0.03 \\
0.05\end{array}$ & $\begin{array}{r}(14.36) \\
(3.95) \\
(1.38)\end{array}$ & $\begin{array}{r}\mathbf{0 . 6 7} \\
\mathbf{0 . 1 2} \\
-\mathbf{0 . 0 4}\end{array}$ & $\begin{array}{r}(10.55) \\
(2.66) \\
(1.71)\end{array}$ \\
\hline$r^{2}$ & $\begin{array}{l}\text { Ap } \\
\text { EB } \\
\text { Bt }\end{array}$ & $\begin{array}{l}0.94 \\
0.74 \\
0.78\end{array}$ & $\begin{array}{l}(0.72) \\
(\mathbf{0 . 7 6 )} \\
(\mathbf{0 . 8 8})\end{array}$ & $\begin{array}{l}0.90 \\
0.88 \\
0.59\end{array}$ & $\begin{array}{l} \\
(0.68) \\
(0.91) \\
(0.96)\end{array}$ & $\begin{array}{l}0.99 \\
0.99 \\
0.97\end{array}$ & $\begin{array}{l}(0.92) \\
(0.96) \\
(0.97)\end{array}$ & $\begin{array}{l}0.99 \\
1.00 \\
0.99\end{array}$ & $\begin{array}{l}(0.98) \\
(0.97) \\
(0.97)\end{array}$ \\
\hline
\end{tabular}


Table 4. Fitted partition coefficients, $m$, the parameter, $b$, the nil-point concentration, $C_{\mathrm{np}}$, and the linear correlation coefficients, $r^{2}$, for the dissolved organic phosphorus (DOP) initial mass (IM) isotherms for the Ap, EB, and Bt horizons at pH 5 and 7 (in parenthesis).

\begin{tabular}{|c|c|c|c|c|c|c|c|c|c|}
\hline IM parameter & Horizon & & & & & & & & \\
\hline$m$ & $\begin{array}{l}\text { Ap } \\
\text { EB } \\
\text { Bt }\end{array}$ & $\begin{array}{l}0.38 \\
0.25 \\
0.47\end{array}$ & $\begin{array}{l}(0.35) \\
(0.46) \\
(0.31)\end{array}$ & $\begin{array}{l}0.35 \\
0.37 \\
0.40\end{array}$ & $\begin{array}{l}(0.38) \\
(0.44) \\
(0.39) \\
\end{array}$ & $\begin{array}{l}0.56 \\
0.44 \\
0.53 \\
-1 \\
\end{array}$ & $\begin{array}{l}(0.50) \\
(0.57) \\
(0.33)\end{array}$ & $\begin{array}{l}0.73 \\
0.64 \\
0.47\end{array}$ & $\begin{array}{l}(0.56) \\
(0.56) \\
(0.31)\end{array}$ \\
\hline$-\boldsymbol{b}$ & $\begin{array}{l}\text { Ap } \\
\text { EB } \\
\mathbf{B t}\end{array}$ & $\begin{array}{l}0.10 \\
0.02 \\
0.02\end{array}$ & $\begin{array}{l}(0.08) \\
(0.09) \\
(0.20)\end{array}$ & $\begin{array}{l}0.10 \\
0.03 \\
0.01\end{array}$ & $\begin{array}{r}(0.07) \\
(0.08) \\
(0.19) \\
\end{array}$ & $\begin{array}{l}0.11 \\
0.02 \\
0.06 \\
\end{array}$ & $\begin{array}{l}(0.08) \\
(0.09) \\
(0.18)\end{array}$ & $\begin{array}{l}0.12 \\
0.03 \\
0.01\end{array}$ & $\begin{array}{l}(0.09) \\
(0.09) \\
(0.21)\end{array}$ \\
\hline$C_{\mathrm{np}}$ & $\begin{array}{l}\mathbf{A p} \\
\mathbf{E B} \\
\mathbf{B t}\end{array}$ & $\begin{array}{l}0.022 \\
0.008 \\
0.003\end{array}$ & $\begin{array}{l}(0.019) \\
(0.018) \\
(0.057)\end{array}$ & $\begin{array}{l}0.024 \\
0.006 \\
0.002\end{array}$ & $\begin{array}{l}(0.015) \\
(0.016) \\
(0.044)\end{array}$ & $\begin{array}{l}0.016 \\
0.004 \\
0.010\end{array}$ & $\begin{array}{l}(0.012) \\
(\mathbf{0 . 0 1 4 )} \\
(\mathbf{0 . 0 4 7 )}\end{array}$ & $\begin{array}{l}0.013 \\
0.004 \\
0.002\end{array}$ & $\begin{array}{r}(0.013) \\
(0.015) \\
(0.058)\end{array}$ \\
\hline$r^{2}$ & $\begin{array}{l}\mathbf{A p} \\
\mathbf{E B} \\
\mathbf{B t}\end{array}$ & $\begin{array}{l}0.98 \\
0.70 \\
0.93\end{array}$ & $\begin{array}{l}(0.95) \\
(0.94) \\
(0.96)\end{array}$ & $\begin{array}{l}0.96 \\
0.81 \\
0.96\end{array}$ & $\begin{array}{r}(0.98) \\
(0.97) \\
(0.86)\end{array}$ & $\begin{array}{l}0.97 \\
0.92 \\
0.94\end{array}$ & $\begin{array}{l}(0.99) \\
(0.99) \\
(0.82)\end{array}$ & $\begin{array}{l}0.99 \\
0.88 \\
0.86\end{array}$ & $\begin{array}{l}(0.98) \\
(0.98) \\
(0.94)\end{array}$ \\
\hline
\end{tabular}

$C_{\mathrm{np}}$ approaches a constant level after $24 \mathrm{~h}$. However, within the $72 \mathrm{~h}$ of reaction $C_{\mathrm{np}}$ did not approach a constant level when sorption was dominating.

\section{Modeling Dissolved Organic Phosphorus and Dissolved Organic Carbon Sorption/Desorption}

To simulate the change of DOC and DOP concentration with time by use of Eq. [6], the parameters of equilibrium concentration, $C_{\mathrm{eq}}$, and the rate constant, $k$, were estimated for each horizon and $\mathrm{pH}$ value. The results of the nonlinear least-square optimization of the parameters are listed in Table 5. The fitted $C_{\text {eq }}$ was close to the asymptotic levels of the $C_{\mathrm{np}}$ vs. time curves, which can be constructed from the data in Tables 3 and 4 .

In general, the rate constant was relatively low for both DOC and DOP at $\mathrm{pH} 7$ compared with the rate constants determined at $\mathrm{pH}$ 5. The average rate constant of DOC approaches $\bar{k}=0.021 \pm 0.009 \mathrm{~h}^{-1}$ at $\mathrm{pH} 5$ and $\bar{k}=0.003 \pm 0.001 \mathrm{~h}^{-1}$ at $\mathrm{pH}$ 7. For DOP the average rate constant approaches $\bar{k}=0.009 \pm 0.006 \mathrm{~h}^{-1}$ at pH 5 and $\bar{k}=0.004 \pm 0.003 \mathrm{~h}^{-1}$ at $\mathrm{pH} 7$ (Table 5). In general, with only two exceptions, the equilibrium concentrations for both DOC and DOP were lower at $\mathrm{pH} 5$ than at $\mathrm{pH}$ 7. For DOC the equilibrium concentration decreased with depth of the horizon for both $\mathrm{pH}$ values. For DOP the equilibrium concentration varied to a lesser extent (Table 5). The two parameters, $k$ and

Table 5. Fitted equilibrium concentrations, $C_{\text {eq, }}$, the rate constants, $k$, and coefficient of determination, $r^{2}$, by nonlinear least-square optimization of Eq. [6] to sorption data.

\begin{tabular}{|c|c|c|c|c|c|c|}
\hline \multirow[b]{3}{*}{$\underline{\text { Parameter } \dagger}$} & \multicolumn{6}{|c|}{ Horizon } \\
\hline & \multicolumn{2}{|c|}{ Ap } & \multicolumn{2}{|c|}{ EB } & \multicolumn{2}{|c|}{ Bt } \\
\hline & pH 5 & pH 7 & pH 5 & pH 7 & pH 5 & pH 7 \\
\hline \multicolumn{7}{|l|}{ DOC } \\
\hline$C_{\mathrm{eq}}, \mathbf{m m o l ~ \mathrm { L } ^ { - 1 }}$ & 0.438 & 6.596 & 0.230 & 1.404 & $\mathbf{0 . 0 7 5}$ & 0.000 \\
\hline$k, \mathbf{h}^{-1}$ & 0.014 & 0.002 & 0.032 & 0.003 & 0.018 & 0.003 \\
\hline$r^{2}$ & 0.985 & 0.997 & 0.991 & 0.998 & 0.963 & 0.986 \\
\hline \multicolumn{7}{|l|}{ DOP } \\
\hline$C_{\text {eq }}, \operatorname{mmol~L} \mathbf{L}^{-1}$ & 0.011 & 0.007 & 0.000 & 0.009 & 0.011 & 0.013 \\
\hline$k, \mathbf{h}^{-1}$ & 0.012 & 0.007 & 0.013 & 0.005 & 0.002 & 0.000 \\
\hline$r^{2}$ & 0.974 & 0.956 & 0.958 & 0.933 & 0.853 & 0.928 \\
\hline
\end{tabular}

$\dagger$ DOC, dissolved organic matter; DOP, dissolved organic phosphorus.
$C_{\text {eq }}$, have a larger variability for DOC than for DOP with change in soil horizon and soil $\mathrm{pH}$, reflecting that the dynamics of DOC sorption/desorption was more sensitive to changes in $\mathrm{pH}$ and soil composition than the dynamics of DOP sorption/desorption.

Equation [6] was used to simulate the dynamics of DOC and DOP sorption and desorption with time using the optimized parameters listed in Table 5. Examples of the fitted DOC and DOP concentrations with time of reaction were shown for the Ap horizon in Fig. 3 and 4, respectively. In general, the curves fit reasonably well, with coefficients of determination $R^{2}>0.963$ for DOC and $R^{2}>0.853$ for DOP (Table 5). The ability of the model to simulate the sorption reaction is also displayed in Fig. 5 which compares measured and predicted values of concentrations of DOC and DOP in the soil-water system for all soil horizons, $\mathrm{pH}$ values, and sampling times.

\section{DISCUSSION}

\section{Effect of pH on Dissolved Organic Matter Sorption}

Sorption of DOC decreased at increasing $\mathrm{pH}$ and extensive desorption was observed at $\mathrm{pH} 7$, especially for the topsoil (Fig. 1). Sorption of DOP exhibited similar $\mathrm{pH}$ dependence although less pronounced. The most marked $\mathrm{pH}$ dependence of DOP sorption was shown by
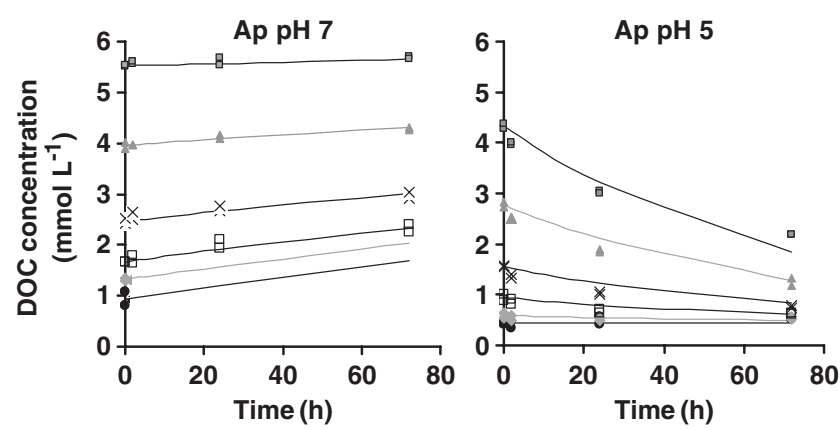

- $0 \mathrm{mmol} \mathrm{L-1DOC} \quad 0.4 \mathrm{mmol} \mathrm{L-1DOC} \square 0.8 \mathrm{mmol} \mathrm{L-1DOC}$

$\times 1.7 \mathrm{mmol}$ L-1DOC $\triangle 3.2 \mathrm{mmol}$ L-1DOC $\quad 4.7 \mathrm{mmol}$ L-1DOC

Fig. 3. Simulated (Eq. [6], lines) and measured (dots) dissolved organic carbon (DOC) concentrations vs. time of reaction for different initial concentrations of DOC added. 


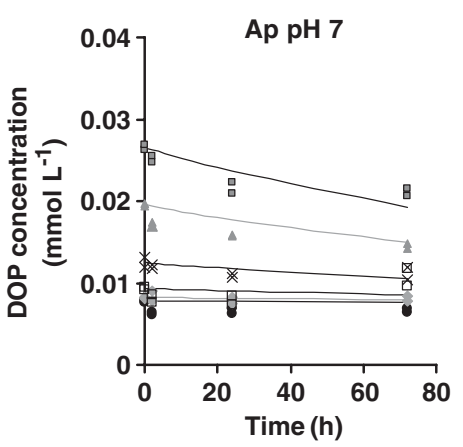

- 0 mmol L-1 DOP 口 $0.005 \mathrm{mmol}$ L-1 DOP $0.020 \mathrm{mmol} \mathrm{L-1}$ DOP

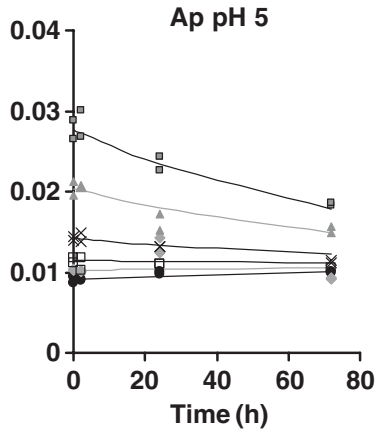

$0.003 \mathrm{mmol}$ L-1 DOP $\times 0.011 \mathrm{mmol} \mathrm{L-1}$ DOP $0.03 \mathrm{mmol}$ L-1 DOP
Fig. 4. Simulated (Eq. [6], lines) and measured (dots) dissolved organic phosphorus (DOP) concentrations vs. time of reaction for different initial concentrations of DOP added.

the $\mathrm{Bt}$ horizon with net DOP sorption at $\mathrm{pH} 5$ but net release at $\mathrm{pH}$ 7. The observed higher DOC sorption at decreasing $\mathrm{pH}$ (Fig. 1) was in agreement with previous studies indicating sorption by variable-charge components such as metal oxides to occur by a ligand exchange mechanism (Kaiser et al., 1996; Shen, 1999).

Contrary to DOC, limited information exists about the pH-dependency of DOP sorption. The main components of DOP are often found to include mono- and diester phosphates. If DOP was sorbed by the phosphate group by ligand-exchange to metal oxides then decreasing $\mathrm{pH}$ should result in a stronger retention of DOP. This appeared to be confirmed in this study as DOP sorption was more pronounced at $\mathrm{pH} 5$ than at $\mathrm{pH} 7$, especially for the Bt horizon. Celi et al. (2001) also found that the $\mathrm{pH}$-dependent sorption of inositol hexaphosphate with goethite was affected by background ionic composition. When $\mathrm{pH}$ increased the retention of inositol hexaphosphate decreased in the presence of $\mathrm{K}^{+}$and increased with $\mathrm{Ca}^{2+}$ in the solution. In supplementary investigations, the background ionic composition of $\mathrm{NaCl}$ was substituted with $\mathrm{CaCl}_{2}$. For the $\mathrm{Bt}$ horizon this resulted in a marked increase in DOP sorption at $\mathrm{pH} 7$ (not shown). However, for DOC the ionic composition may have the opposite effects. Erich and Trusty (1997) investigated the effect of an increase in $\mathrm{pH}$ due to liming on DOM in water extracts of organic horizons from nine forested sites. The addition of lime $\left(\mathrm{CaCO}_{3}\right)$ to organic horizons caused an average of $55 \%$ more $\mathrm{C}$ to be released than in unamended samples. Thus, liming may favor desorption of DOC and sorption of DOP.

\section{Fractionation of Dissolved Organic Matter}

The relationships between molar DOC/DOP ratios and DOC concentrations were shown in Fig. 6 for the two $\mathrm{pH}$ values. When DOC/DOP ratios in the solution after sorption were higher than in the applied DOM $(\mathrm{DOC} / \mathrm{DOP}=158$, Table 2$)$, then the solution was enriched with DOC and/or DOP had been removed from solution. If the DOC/DOP ratio was lower than in the applied DOM, then preferential DOC sorption and/or DOP release took place. In general, the DOC/DOP ratio in the solutions from the sorption experiments increased with increasing DOC concentrations. The DOC/DOP ratio shown as a function of DOC concentration exhibited very different patterns at the two $\mathrm{pH}$ values and for the different horizons (Fig. 6). At pH 5, DOC/DOP increased at increasing DOC concentration approaching the ratio in the DOM extract for all three soil samples, i.e., the solution phase was enriched with DOP. In contrast, the DOC/DOP ratio was strongly soil dependent at $\mathrm{pH}$ 7. The solution in contact with the Ap horizon was enriched in DOC, while contact with the Bt horizon led to DOP enrichment of the solution phase; the effect of the EB horizon was in between those of Ap and Bt. However, at DOC concentrations below about $2 \mathrm{mmol} \mathrm{L}^{-1}$ the effect of DOM sorption/desorption generally resulted in DOP enrichment of the solution phase.

The results obtained in this study indicated that DOM fractionation by sorption and desorption to agricultural soil could not be explained by simple relationships to soil factors. The fractionation might be due to preferential sorption by a specific DOM fraction as observed in forest soils (Kaiser et al., 1996; Ussiri and Johnson, 2004). However, the molecular size distribution or the hydrophobic properties before and after sorption was
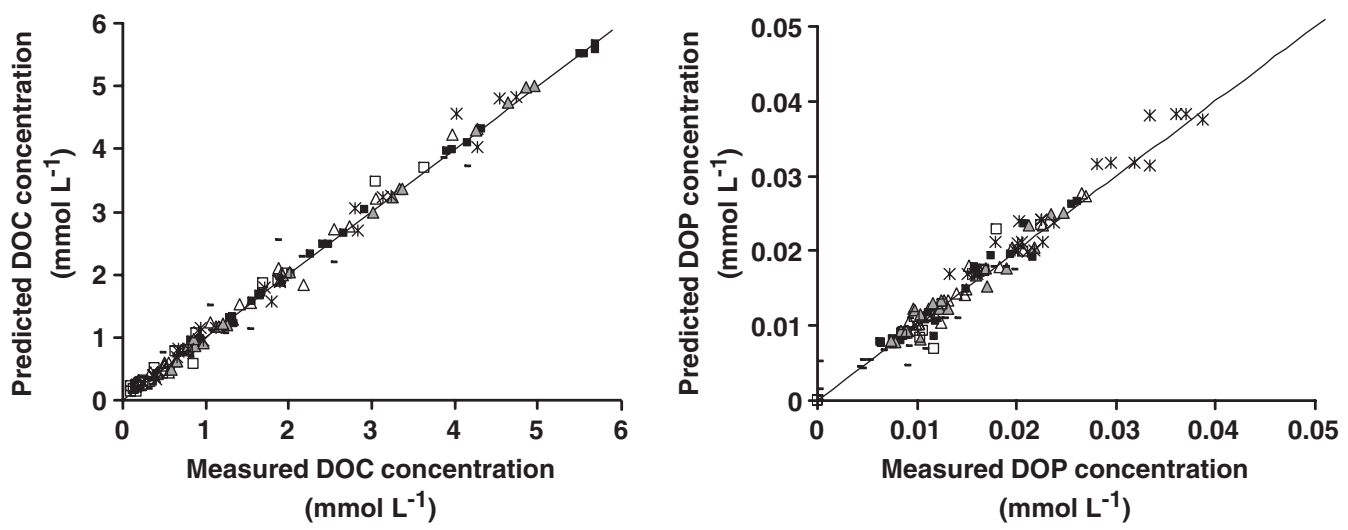

- Ap pH $7 \Delta$ Ap pH $5 \Delta$ EB pH 7

ㄷ EB pH $5 \quad *$ Bt pH 7 - Bt pH $5-1: 1$

Fig. 5. Comparison of measured and simulated (Eq. [6]) values of dissolved organic C (DOC) (left) and dissolved organic P (DOP) (right) concentrations for all samples investigated. The line $1: 1$ indicates where a measured value is equal to a simulated value. 


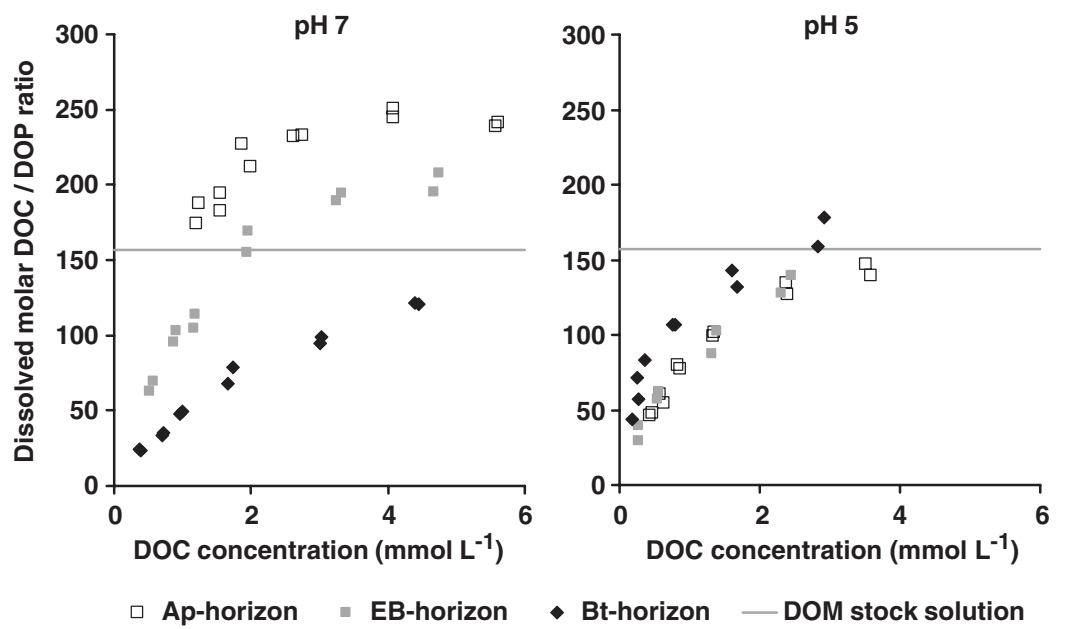

Fig. 6. Fractionation of dissolved organic carbon (DOC) and dissolved organic phosphorus (DOP) during sorption represented by the DOC/DOP ratios in solution vs. dissolved DOC concentration for $\mathrm{Ap}, \mathrm{EB}$, and Bt horizons at pH 7 (left) and pH 5 (right). Dots correspond to averages for all reaction times for each soil sample.

not measured in these experiments. The results obtained here showed that sorption was probably correlated with an exchange reaction releasing DOM fractions with relatively high $\mathrm{P}$ content and low $\mathrm{C}$ contents. The extent of DOM fractionation depended on concentration level, $\mathrm{pH}$, and whether the soil was topsoil or subsoil. Changing these soil factors by change in soil management might change the mobility of especially DOC, but also DOP in the subsoil. Hence, if $\mathrm{pH}$ was decreasing due to change in soil use (i.e., afforestation) the result could be a decrease in DOC leaching and vice versa.

The question is whether the fractionation of DOM is important for quantifying the leaching of DOP. As an example, an agricultural field (Humic Hapludult) with an annual matrix percolation of $380 \mathrm{~mm}$, an average content of $60 \mathrm{~kg} \mathrm{DOC} \mathrm{ha}{ }^{-1}$, and $560 \mathrm{~mm}$ water in the top $2 \mathrm{~m}$ of the soil profile, corresponding to an average DOC concentration of $0.9 \mathrm{mmol} \mathrm{L}^{-1}$ in the profile, is selected. The initial DOC/DOP ratio of the DOM is 158 . At this DOC concentration and DOC/DOP ratio a fractionation of DOM by sorption occurs, especially at acid $\mathrm{pH}$ values. If no fractionation occurs, there would be an annual loss of $0.7 \mathrm{~kg}$ DOP ha ${ }^{-1}$ due to convective transport in the soil profile. However, if fractionation is taken into account, then the DOP concentration in the solution will increase, which results in an increase in leaching by approximately $60 \%$. Thus, the fractionation is important when quantifying the leaching of DOP.

\section{Sorption Kinetics}

When the DOC and DOP sorption, which had occurred after $72 \mathrm{~h}$ was set equal to $100 \%$, the percentage sorption, after $1 \mathrm{~min}, 2 \mathrm{~h}$, and $24 \mathrm{~h}$ of reaction, could be estimated as averages of samples over the concentration range, horizons, and $\mathrm{pH}$. Approximately 50 to $60 \%$ of the DOC and DOP sorption occurred during the first $1 \mathrm{~min}$ of reaction. After $24 \mathrm{~h}$ approximately 80 to $90 \%$ of DOC and DOP sorption had taken place. Thus, most of the DOC and DOP sorption occurred during the first minutes of reaction. A pre-study conducted by Moore et al. (1992) using soil samples initially containing $40 \mathrm{mg}$ DOC $\mathrm{L}^{-1}$, showed that $>90 \%$ of the sorption developed over $48 \mathrm{~h}$ occurred during the first $24 \mathrm{~h}$ of reaction, and most occurred in the first $2 \mathrm{~h}$. McDowell and Wood (1984) also noted that equilibrium was essentially complete after $2 \mathrm{~h}$ of reaction.

As shown in Table 3, the $C_{\mathrm{np}}$ estimated from the IM isotherms changes considerably from 24 to $72 \mathrm{~h}$. Most of the sorption and/or desorption took place during the first couple of hours. However, the equilibrium was probably not fully obtained within the studied $72 \mathrm{~h}$ as the fitted $C_{\text {eq }}$ (Table 5) differs from the observed nil-point concentrations, $C_{\mathrm{np}}$, determined after $72 \mathrm{~h}$ (Table 3 ). Hence, estimating the equilibrium concentration, $C_{\mathrm{eq}}$, of DOC from pedotransfer functions, which was based on 24-h experiments (Moore et al., 1992; Kaiser et al., 1996), is likely to overestimate $C_{\text {eq }}$ when the soil sorbs DOM and to underestimate $C_{\mathrm{eq}}$ when the soil desorbs DOM, as "equilibrium" was not fully established within $24 \mathrm{~h}$.

\section{Modeling Dissolved Organic Phosphorus and Dissolved Organic Carbon Sorption/Desorption}

The kinetic simulation of DOC sorption/desorption was more sensitive to changes in $\mathrm{pH}$ and soil composition than the simulation of DOP sorption/desorption, which was reflected in the larger variability of the two parameters, $k$ and $C_{\text {eq }}$, with change in soil and $\mathrm{pH}$. The strength of this modeling approach is that only two parameters are needed to describe the sorption dynamics when up-scaling to field-scale models. The model is applicable at different $\mathrm{pH}$ values. However, to model the DOM mobility at field scale the two parameters, $k$ and $C_{\text {eq }}$, need to be parameterized by taking into account soil properties and $\mathrm{pH}$ of soil solution. Pedotransfer functions estimating these parameters must be obtained from experiments where long reaction times are used to ensure "equilibrium." Care must be considered by using the existing pedotransfer functions developed for determinations of $C_{\mathrm{eq}}$ from IM isotherms obtained after short reaction times. 
In the field, the DOM sorption/desorption process might be limited by diffusion, which was eliminated in the batch experiments. Thus, the value of $k$ will probably be affected by diffusion time and distance. Between soil treatments such as tillage or addition of nutrients, the DOM sorption/desorption will probably be close to equilibrium. However, right after application of manure or soil plowing in field soils, high concentration levels of DOC or DOP probably occur in solution, which influence the sorption dynamic due to a large concentration gradient. The model concept presented here works with the DOC concentration ranges found in agricultural soils and it incorporates the effect of DOC concentration into the sorption/desorption dynamics.

The simulation of the time-dependent sorption/desorption dynamics are useful for future incorporation of DOP into field-scale models. Modeling DOP and DOC at field scale also includes a full description of turnover of organic matter and transport of DOC and DOP through the soil.

\section{CONCLUSIONS}

In general, more that 80 to $90 \%$ of the DOC and DOP sorption/desorption took place during $24 \mathrm{~h}$; however, the equilibrium was not fully obtained within $72 \mathrm{~h}$. The IM isotherms were able to describe the DOC and DOP sorption isotherm after $24 \mathrm{~h}$ of reaction. There was a very pronounced effect of $\mathrm{pH}$ resulting in much higher sorption of DOC at $\mathrm{pH} 5$ than at $\mathrm{pH}$ 7. Extensive desorption was observed at $\mathrm{pH} 7$, especially for the topsoil. Thus, $\mathrm{pH}$ exerts a strong control on the mobility of DOC. Similar sorption patterns were observed for DOP, but they were not as pronounced as for DOC and $\mathrm{pH}$ exerted a minor control of DOP sorption in subsoil horizons.

Generally, the effect of DOM sorption/desorption resulted in a decrease of the DOC/DOP ratio in solution at low DOM concentrations. Hence, our results support the findings that a fractionation occurs after DOM sorption/ desorption making the soluble fraction of DOM enriched with P. The fractionation was important at relatively low DOC concentrations $\left(<2 \mathrm{mmol} \mathrm{L}^{-1}\right)$ often found in agricultural soils. The fractionation increased the relative loss of DOP from the root zone and was therefore important when quantifying the leaching of DOC and DOP.

The model was capable of simulating the kinetics of DOC and DOP sorption/desorption as a function of the deviation of solution DOC and DOP concentrations from corresponding "equilibrium" concentrations. Thus, it was possible to describe the sorption and desorption with only two parameters (i.e., $k$ and $C_{\text {eq }}$ ). Approximate $C_{\text {eq }}$ may be estimated from pedotransfer functions. The optimized value of the parameter $k$ had only minor variations with change in $\mathrm{pH}$ and horizon. However, more testing is needed before it can be used in field-scale models. Additionally, when up-scaling to field scale, the value of $k$ will also be affected by diffusion time and distance.

\section{ACKNOWLEDGMENTS}

The results presented were part of a research program "Regional Groundwater Protection by Optimized Organic
Farming Systems" financed by the Danish Research Centre for Organic Farming, in cooperation with an industrial Ph.D. project at DHI Water \& Environment in association with The Royal Veterinary and Agricultural University financed by The Danish Academy of Technical Science.

\section{REFERENCES}

Abrahamsen, P., and S. Hansen. 2000. Daisy: An open soil-cropatmosphere system model. Environ. Modell. Soft. 15:313-330.

Ashworth, D.J., and B.J. Alloway. 2004. Soil mobility of sewage sludgederived dissolved organic matter, copper, nickel, and zinc. Environ. Pollut. 127:137-144.

Bedrock, C.N., M.V. Cheshire, J.A. Chudek, A.R. Fraser, B.A. Goodman, and C.A. Shand. 1995. Effect of $\mathrm{pH}$ on precipitation of humic acid from peat and mineral soils on the distribution of phosphorus forms in humic and fulvic acid fractions. Commun. Soil Sci. Plant Anal. 26:1411-1425.

Borggaard, O.K., C. Szilas, A.L. Gimsing, and L.H. Rasmussen. 2004. Estimation of soil phosphate adsorption capacity by means of a pedotransfer function. Geoderma 118:55-61.

Buffle, J. 1990. Complexation reactions in aquatic systems: An analytical approach. Ellis Horwood Ltd., Chichester, UK.

Cambier, P., and G. Sposito. 1991. Interactions of citric-acid and synthetic hydroxyaluminum montmorillonite. Clays Clay Miner. 39: 158-166.

Celi, L., S. Lamacchia, F. Ajmore-Marsan, and E. Barberis. 1999. Interaction of inositol hexaphosphate on clays: Adsorption and charging phenomena. Soil Sci. 164:574-585.

Celi, L., M. Presta, F. Ajmore-Marsan, and E. Barberis. 2001. Effects of $\mathrm{pH}$ and electrolytes on inositol hexaphosphate interaction with goethite. Soil Sci. Soc. Am. J. 65:753-760.

Chapman, H.D. 1965. Cation exchange capacity. p. 891-901. In C.A. Black et al (ed.) Methods of soil analysis: Part 1. Chemical and microbiological properties. ASA, Madison, WI.

DHI Water and Environment. 2001. MIKE SHE water quality user manual. DHI Water \& Environment, Hoersholm, Denmark.

ELTRA. 1995. CS500 Simultaneous carbon/sulfur determinator. ELTRA GmbH, Neuss, Germany.

Erich, M.S., and G.M. Trusty. 1997. Chemical characterization of dissolved organic matter released by limed and unlimed forest soil horizons. Can. J. Soil Sci. 77:405-413.

Fila, G., M. Donatelli, and G. Bellocchi. 2006. PTFIndicator: An IRENE_DLL-based application to evaluate estimates from pedotransfer functions by integrated indices. Environ. Modell. Soft. 21: 107-110.

Flores-Céspedes, F., M. Fernandez-Perez, M. Villafranca-Sanchez, and E. Gonzalez-Pradas. 2006. Cosorption study of organic pollutants and dissolved organic matter in soil. Environ. Pollut. 142:449-456.

Gee, G.W., and J.W. Bauder. 1986. Particle-size analysis. p. 383-409. In A. Klute (ed.) Methods of soil analysis: Part I. Physical and mineralogical methods. ASA and SSSA, Madison, WI.

Gerritse, R.G. 1996. Column- and catchment-scale transport of cadmium: Effect of dissolved organic matter. J. Contam. Hydrol. 22: $145-163$.

Gjettermann, B., M. Styczen, H.C.B. Hansen, F.P. Vinther, and S. Hansen. 2006. Modelling dissolved organic matter dynamics in agricultural soil using DAISY. Ecol. Modell. (in review).

Grant, R., A. Laubel, B. Kronvang, H.E. Andersen, L.M. Svendsen, and A. Fuglsang. 1996. Loss of dissolved and particulate phosphorus from arable catchments by subsurface drainage. Water Res. 30:2633-2642.

Guggenberger, G., and K. Kaiser. 2003. Dissolved organic matter in soil: Challenging the paradigm of sorptive preservation. Geoderma 113:293-310

Hagedorn, F., M. Saurer, and P. Blaser. 2004. A C-13 tracer study to identify the origin of dissolved organic carbon in forested mineral soils. Eur. J. Soil Sci. 55:91-100.

Horn, A.L., W. Reiher, R.A. During, and S. Gath. 2006. Efficiency of pedotransfer functions describing cadmium sorption in soils. Water Air Soil Pollut. 170:229-247.

Janse, T.A.H.M., P.F.A. Van Der Weil, and G. Kateman. 1983. Experimental optimization procedures in the determination of phosphate by flow-injection analysis. Anal. Chim. Acta 155:89-102. 
Kaiser, K. 2001. Dissolved organic phosphorus and sulphur as influenced by sorptive interactions with mineral subsoil horizons. Eur. J. Soil Sci. 52:489-493.

Kaiser, K. 2003. Sorption of natural organic matter fractions to goethite (alpha-FeOOH): Effect of chemical composition as revealed by liquid-state C-13 NMR and wet-chemical analysis. Org. Geochem. 34:1569-1579.

Kaiser, K., G. Guggenberger, L. Haumaier, and W. Zech. 1997. Dissolved organic matter sorption on subsoils and minerals studied by C-13-NMR and DRIFT spectroscopy. Eur. J. Soil Sci. 48:301-310.

Kaiser, K., G. Guggenberger, and W. Zech. 1996. Sorption of DOM and DOM fractions to forest soils. Geoderma 74:281-303.

Kaiser, K., and W. Zech. 2000. Sorption of dissolved organic nitrogen by acid subsoil horizons and individual mineral phases. Eur. J. Soil Sci. 51:403-411.

Lilienfein, J., R.G. Qualls, S.M. Uselman, and S.D. Bridgham. 2004. Adsorption of dissolved organic and inorganic phosphorus in soils of a weathering chronosequence. Soil Sci. Soc. Am. J. 68:620-628.

Marschner, B., and K. Kalbitz. 2003. Controls of bioavailability and biodegradability of dissolved organic matter in soils. Geoderma 113: 211-235.

McDowell, W.H. and T. Wood. 1984. Podsolization: Soil processed control dissolved organic carbon concentrations in stream water. Soil Sci. 137:23-32.

Mehra, O.P., and M.L. Jackson. 1960. Iron oxide removal from soils and clays by dithionite-citrate systems buffered with sodium bicarbonate. p. 317-327. In A. Swineford (ed.) Clays and clay minerals Proceedings of the 7 th national conf. on clays and clay minerals. Washington, DC.

Michalzik, B., E. Tipping, J. Mulder, J.F.G. Lancho, E. Matzner, C.L. Bryant, N. Clarke, S. Lofts, and M.A.V. Esteban. 2003. Modelling the production and transport of dissolved organic carbon in forest soils. Biogeochemistry 66:241-264.

Moore, T.R., W. Desouza, and J.F. Koprivnjak. 1992. Controls on the sorption of dissolved organic-carbon by soils. Soil Sci. 154:120-129.

Neff, J.C., and G.P. Asner. 2001. Dissolved organic carbon in terrestrial ecosystems: Synthesis and a model. Ecosystems 4:29-48.

Nodvin, S.C., C.T. Driscoll, and G.E. Likens. 1986. Simple partitioning of anions and dissolved organic carbon in a forest soil. Soil Sci. 142:27-35.

Qualls, R.G., and B.L. Haines. 1991. Geochemistry of dissolved organic nutrients in water percolating through a forest ecosystem. Soil Sci. Soc. Am. J. 55:1112-1123.

Renaud, F.G., P.B. Leeds-Harrison, C.D. Brown, and W. van Beinum. 2004. Determination of time-dependent partition coefficients for several pesticides using diffusion theory. Chemosphere 57 $1525-1535$.

Schwertmann, U. 1964. Differzierung der eisenoxide des bodenss durch extraction mit ammoniumoxalat-lösung. Z. Pflanzenernaehr. Dueng. Bodenkd. 105:194-202.

Shen, Y.H. 1999. Sorption of natural dissolved organic matter on soil. Chemosphere 38:1505-1515.

Slavich, P.G., and G.H. Petterson. 1993. Estimating the electricalconductivity of saturated paste extracts from 1-5 soil, water suspensions and texture. Aust. J. Soil Res. 31:73-81.

Soil Survey Staff. 1999. Keys to soil taxonomy. Pocahontas Press, Blacksburg, VI.

Szilas, C.P., O.K. Borggaard, H.C.B. Hansen, and J. Rauer. 1998. Potential iron and phosphate mobilization during flooding of soil material. Water Air Soil Pollut. 106:97-109.

Ussiri, D.A.N., and C.E. Johnson. 2004. Sorption of organic carbon fractions by Spodosol mineral horizons. Soil Sci. Soc. Am. J. 68:253-262.

Vance, G.F., and M.B. David. 1992. Dissolved organic-carbon and sulfate sorption by spodosol mineral horizons. Soil Sci. 154:136-144.

Vinther, F.P., E.M. Hansen, and J. Eriksen. 2005. Leaching of soil organic carbon and nitrogen in sandy soils after cultivating grassclover swards. Biol. Fertil. Soils 43:12-19.

Wang, L.L., Y.P. Chin, and S.J. Traina. 1997. Adsorption of (poly)maleic acid and an aquatic fulvic acid by goethite. Geochim. Cosmochim. Acta 61:5313-5324.

Wraith, J.M., and D. Or. 1998. Nonlinear parameter estimation using spreadsheet software. J. Nat. Resour. Life Sci. Educ. 27:13-17.

Yang, Y., D. Ratte, B.F. Smets, J.J. Pignatello, and D. Grasso. 2001 Mobilization of soil organic matter by complexing agents and implications for polycyclic aromatic hydrocarbon desorption. Chemosphere 43:1013-1021. 